\title{
GENETIC SIMILARITY OF CITRUS FRESH FRUIT MARKET CULTIVARS ${ }^{1}$
}

\author{
ROBERTO PEDROSO DE OLIVEIRA² \& ELIZETE BEATRIZ RADMANN ${ }^{3}$
}

\begin{abstract}
The objective of this work was to assess the genetic similarity of the following citrus fresh fruit market seedless cultivars: Lane Late, Navelate, Navelina and Salustiana sweet oranges (Citrus sinensis (L.) Osbeck), Clemenules and Marisol mandarins (C. reticulata Blanco) and Okitsu satsuma mandarin (C. unshiu Marcovitch), and the hybrids Nova [C. clementina $\mathrm{x}$ (C. paradisi $\mathrm{x}$ C. tangerina)] and Ortanique (tangor probably derived from C. sinensis (L.) Osbeck x C. reticulata Blanco), utilizing isoenzymatic markers. Electrophoresis analysis of proteins extracted from leaf tissues was utilized to detect polymorphisms at ten isoenzymatic systems. Out of 30 alleles, 16 were polymorphic. The Jaccard coefficient was utilized to estimate the genetic similarity between the cultivars and the unweigthed pair-group method using an arithmetic average (UPGMA) was used to obtain the phenogram (NTSYS 1.7). The cultivars showed high genetic similarity $(>72.5 \%)$, and were classified in five main groups: sweet oranges, 'Clemenules' and 'Marisol' mandarins, 'Nova', 'Ortanique', and 'Okitsu' satsuma mandarin.
\end{abstract}

Index terms: biochemical markers, genetic similarity, isozymes.

\section{SIMILARIDADE GENÉTICA DE CULTIVARES DE CITROS DE MESA}

RESUMO - O objetivo deste trabalho foi estudar a similaridade genética das seguintes cultivares sem sementes de citros de mesa: laranjas Lane Late, Navelate, Navelina e Salustiana (Citrus sinensis (L.) Osbeck), tangerinas Clemenules e Marisol (C. reticulata Blanco), satsuma Okitsu (C. unshiu Marcovitch) e híbridos Nova [C. clementina x (C. paradisi x C. tangerina)] e Ortanique (tangor provavelmente entre $C$. sinensis (L.) Osbeck e $C$. reticulata Blanco), por intermédio de marcadores isoenzimáticos. O polimorfismo foi detectado por eletroforese de proteínas extraídas de tecido foliar em 10 sistemas isoenzimáticos. Foram obtidos 30 alelos, sendo 16 polimórficos. O coeficiente de Jaccard foi utilizado para estimar a similaridade genética entre as cultivares e o método UPGMA para gerar o fenograma por meio do NTSYS 1,7. As cultivares apresentaram elevada similaridade genética $(>72,5 \%)$ e cinco grupos principais foram detectados: laranjas-doces, tangerinas 'Clemenules' e 'Marisol', 'Nova', 'Ortanique', e satsuma 'Okitsu'.

Termos para indexação: marcadores bioquímicos, similaridade genética, isoenzimas

The citrus production is one of the most important agribusiness, with high economic and social impacts for the Brazilian economy (Agrianual, 2004). Even though Brazil is the largest exporter of orange concentrated juice (IBGE, 2004), the citrus fresh fruit market should be better explored. Bud woods of 'Lane Late', 'Navelate', 'Navelina' and 'Salustiana' sweet oranges (Citrus sinensis (L.) Osbeck), 'Clemenules' and 'Marisol' (C. reticulata Blanco) mandarins and 'Okitsu' satsuma mandarin (C. unshiu Marcovitch), and the hybrids 'Nova' [C. clementina $\mathrm{x}$ (C. paradisi $\mathrm{x}$ C. tangerina)] and 'Ortanique' (natural hybrid, probably derived from the crossing between $C$. sinensis (L.) Osbeck x C. reticulata Blanco) were re-introduced into the country from Uruguay through Embrapa - Centro de Pesquisa Agropecuária de Clima Temperado. These cultivars are seedless, well accepted in international markets and commercially cultivated in several countries.

The taxonomy of the genus Citrus is very complex because of the occurrence of spontaneous mutations, structural chromosomal alterations, and/or interspecific hybridization (Cameron \& Frost, 1968). These facts are important to understand and study genetic diversity and origin and for cultivar management.

Isoenzymatic markers have been extensively utilized for two decades in genetic studies of Citrus, since they are of low cost, easy to be conducted, show codominant inheritance, are related to genomic regions that have only a single copy, and allow the characterization of plants independent of age and season (Herrero et al., 1996).

The objective of this work was to assess the genetic similarity of 'Lane Late', 'Navelate', 'Navelina' and 'Salustiana' sweet oranges, 'Clemenules' and 'Marisol' mandarins, 'Okitsu' satsuma mandarin, and the hybrids 'Nova' and 'Ortanique', utilizing isoenzymatic markers.

As plant materials were investigated the following cultivars: Lane Late, Navelate, Navelina and Salustiana (Citrus sinensis (L.) Osbeck) sweet oranges, 'Clemenules' and 'Marisol' mandarins $(C$. reticulata Blanco), and Okitsu satsuma mandarin (C. unshiu Marcovitch), and hybrids Nova [C. clementina x (C. paradisi $\mathrm{x} C$. tangerina) ] and Ortanique (natural hybrid, probably derived from $C$. sinensis (L.) Osbeck x C. reticulata Blanco). Ten isoenzymatic systems were used, i.e., esterase (EST), acid phosphatase (APS), phosphoglucomutase (PGM), glutamate oxaloacetate transaminase (GOT), isocitrate dehydrogenase (IDH), leucine amino peptidase (LAP), malate dehydrogenase (MDH), peroxidase (PRX), superoxidase dismutase (SOD), and shikimato dehydrogenase (SKDH).

Mature leaves collected from three-year-old citrus mother trees cultivated in $20 \mathrm{~L}$ plastic pot under greenhouse conditions were used for protein extraction. Samples (10 $\mathrm{mg}$ of leaves) were transferred to porcelain plates with round grooves, where they were kept on ice. Each sample had four replications, each processed on different days. Samples were ground with an emery-glass pestle in the presence of specific buffers. Protein extraction was done in the presence of a buffer composed of histidine $\mathrm{pH} 6.5$ with $0.15 \%$ B-mercaptoethanol $(1: 2)$ for the APS, GOT, IDH, LAP, MDH, PGM, PRX, SOD and SKDH. For EST, the buffer contained histidine $\mathrm{pH} 8.3$ with $0.15 \%$ ß-mercaptoethanol (1:1), according to Scandalios (1969). Subsequently, the extract was applied to 3MM Wattmann paper and loaded into $1.5 \times 4.0 \mathrm{~mm}$-well of polyacrylamide gels (PAGE) utilizing a stain steel comb.

The electrophoresis was performed in an horizontal system with 5\% PAGE for IDH, MDH, PGM, SOD and SKDH in the presence of a running buffer according to Shields et al. (1983); with 6\% PAGE for LAP, APS and GOT, and 5\% PAGE for EST and PRX with a running buffer according to Scandalios (1969). Gel electrophoresis was done in a cold room at an average temperature of $4^{\circ} \mathrm{C}$. The potential was kept approximately at $10 \mathrm{~V} \mathrm{~cm}^{-1}$ and the electric current was paralyzed when the bromophenol blue dye reached $9 \mathrm{~cm}$ from the bottom.

The histochemical development of the gels followed the methods based upon Scandalios (1969) for the APS, EST, LAP and PRX; Vallejos (1983) for IDH, PGM and SKDH, and Ayala et al. (1972) for GOT, $\mathrm{MDH}$ and SOD. The gels were maintained at $37^{\circ} \mathrm{C}$ until bands were formed and, subsequently, gels were fixed in a solution composed of distilled water, methanol, and acetic acid (5:5:1).

The interpretation of the zymograms was done based upon the relative mobility of the bands, and only those stable and consistent were selected.

\footnotetext{
${ }_{1}^{1}$ (Trabalho 104/2004). Recebido: 19/08/2004. Aceito para publicação: 05/05/2005.

${ }^{2}$ Eng. Agr ${ }^{\circ}$., Dr., Pesquisador da Embrapa Clima Temperado. Caixa Postal 403. CEP 96001-970. Pelotas-RS. Bolsista CNPq. E-mail: rpedroso@cpact.embrapa.br ${ }^{3}$ Eng. Agr ${ }^{\circ}$., M.Sc., Doutorando na Universidade Federal de Pelotas. Caixa Postal 354. CEP 96001-970. Pelotas-RS. Bolsista CNPq. E-mail: eradmann@hotmail.com
} 
TABLE 1 - Genetic similarity matrix among citrus fresh fruit market cultivars obtained with ten isoenzymatic systems by the Jaccard coefficient.

\begin{tabular}{lrrrrrrrr}
\hline Genetic material & 1 & 2 & 3 & 4 & 5 & 6 & 7 & 9 \\
\hline 1. 'Lanelate' & 1.0000 & & & & & & & \\
2. 'Navelate' & 1.0000 & 1.0000 & & & & & & \\
3. 'Navelina' & 1.0000 & 1.0000 & 1.0000 & & & & \\
4. 'Salustiana' & 1.0000 & 1.0000 & 1.0000 & 1.0000 & & & \\
5. 'Clemenules' & 0.8000 & 0.8000 & 0.8000 & 0.8000 & 1.0000 & & \\
6. 'Marisol' & 0.7805 & 0.7805 & 0.7805 & 0.7805 & 0.9730 & 1.0000 & \\
7. Satsuma 'Okitsu' & 0.7436 & 0.7436 & 0.7436 & 0.7436 & 0.7436 & 0.7250 & 1.0000 & \\
8. 'Nova' & 0.7805 & 0.7805 & 0.7805 & 0.7805 & 0.8718 & 0.8974 & 0.8158 & 1.0000 \\
9. 'Ortanique' & 0.7500 & 0.7500 & 0.7500 & 0.7500 & 0.8919 & 0.8684 & 0.7368 & 0.7750 \\
\hline
\end{tabular}

The Jaccard coefficient was used to estimate the genetic similarity between the parents and hybrids, and the phenogram was obtained based upon the unweigthed pair group arithmetic average method (UPGMA), through the NTSYS 1.7 software (Numerical Taxonomy and Multivariate Analysis System) (Rohlf, 1992). The bootstrap values for each cluster were determined by using the BOOD software (Coelho, 2000).

Thirty alleles were obtained from genetic materials of nine citrus fresh fruit market cultivars with ten isoenzymatic systems. Sixteen alleles showed polymorphic bands at least between two cultivars and the others were monomorphic (Figure 1). The number of polymorphic alleles produced through the isoenzymatic systems EST, APS, PGM, GOT, IDH, LAP, MDH, PRX, SOD and SKDH was 2, 0, 3, 0, 2, 2, 0, 0, 0 and 7 , respectively.

The efficiency of the isozyme technique to produce polymorphic bands among mandarins and hybrids of citrus species and its inefficiency when compared to sweet orange cultivars, and the genetic similarity matrix are demonstrated in this work (Figure 1; Table 1). These results can be explained based upon evolutionary facts, i.e., the differentiation of mandarins is due to natural hybridization processes, while that from sweet oranges is due to spontaneous mutation in only a few genes (Scora, 1975). Therefore, it has been very difficult to differentiate sweet orange cultivars even using molecular markers such as RFLP (Restriction Fragment Length Polymorphism), RAPD (Random Amplified Polymorphic DNA) and micro satellites (Novelli et al., 2000), although there are phenotypic differences between these plants.

The genetic analyses showed that the cultivars had high genetic similarity $(>72.5 \%$ ) (Table 1$)$. Similar results were previously documented by Oliveira et al. (2002), who evaluated different cultivars of $C$. sinensis and $C$. reticulata. In spite of the high similarity observed, the cultivars were clustered into five groups according to the phenogram obtained via the UPGMA method. Group I comprises 'Lanelate', 'Navelate', 'Navelina' and 'Salustiana' sweet oranges; group II was formed by the 'Clemenules' and 'Marisol' mandarins; group III clustered the hybrid 'Nova', while group IV had the hybrid 'Ortanique', and group $\mathrm{V}$ was formed by the 'Okitsu' satsuma mandarin (Figure 2). Clusters I and II showed the greatest consistency in the bootstrap analyses, with $100 \%$ and $87 \%$, respectively.

There are several discrepancies related to the phylogeny and taxonomy of Citrus due to its high variability, spontaneous mutations, apomixes, and cultivation in a wide geographic area (Cameron \& Frost, 1968). Various classification systems were proposed for Citrus, and they differ mainly in the number of known species: 159 (Tanaka, 1977), 16 (Swingle \& Reece, 1967) and 3 (Barret \& Rhodes, 1976). Likewise, there are disagreements for mandarin's taxonomy. Swingle \& Reece (1967) and Coletta Filho et al. (1998) suggest that mandarins should be clustered into one species, even though they agree with the split of the taxonomic groups. On the other hand, Tanaka (1977) classified mandarins in 36 species.

In the present work, the cultivars 'Clemenules' and 'Marisol' showed high genetic similarity $\left(\mathrm{G}_{j} 0.9730\right)$ (Table 1$)$, which was expected because both are considered the same species, C. reticulata, based upon all classification systems in the literature. The hybrids 'Nova' and 'Ortanique' also showed strong genetic similarity with the cultivars

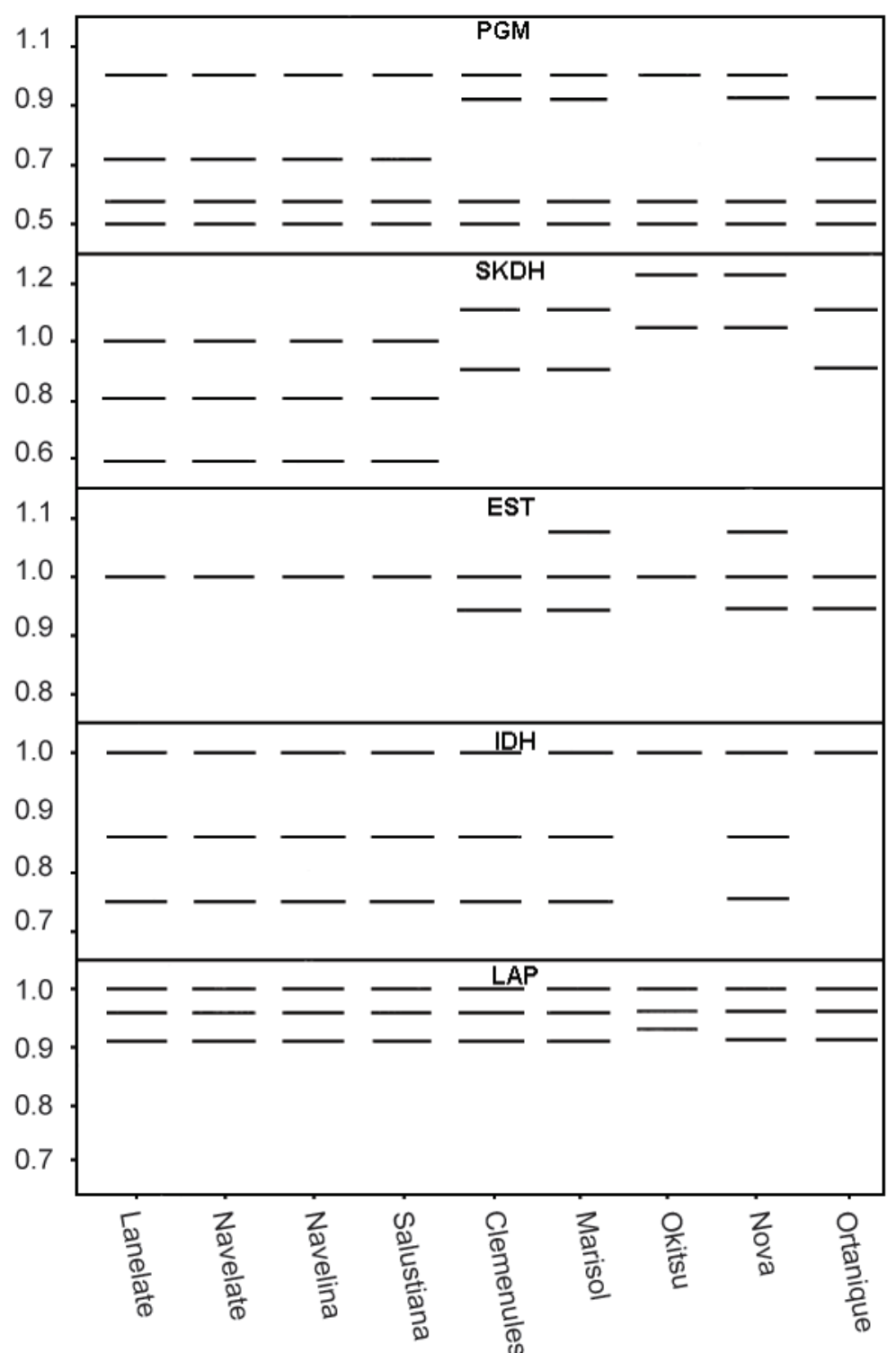

FIGURE 1 - Representation of the isoenzymatic polymorphic banding patterns obtained with the PGM (phosphoglucomutase), SKDH (shikimato dehydrogenase), EST (esterase), IDH (isocitrate dehydrogenase) and LAP (leucine aminopeptidase) in citrus fresh fruit market cultivars.

from $C$. reticulata. 'Ortanique' tangor is considered a natural hybrid between $C$. sinensis and $C$. reticulata, while 'Nova' is a man-made hybrid produced by double crossings [C. clementina $\mathrm{x}(C$. paradisi $\mathrm{x}$ C. tangerina)] (Swingle \& Reece, 1967). Therefore, a higher genetic similarity was expected among 'Ortanique' and the evaluated cultivars from C. reticulata ('Clemenules' and 'Marisol') than for 'Nova'. Coletta Filho et al. (1998) obtained similar results comparing different cultivars from the same species through RAPD markers. They found that hybrids from $C$. clementina $\mathrm{x}$ (C. paradisi $\mathrm{x} C$. tangerina) had higher genetic 


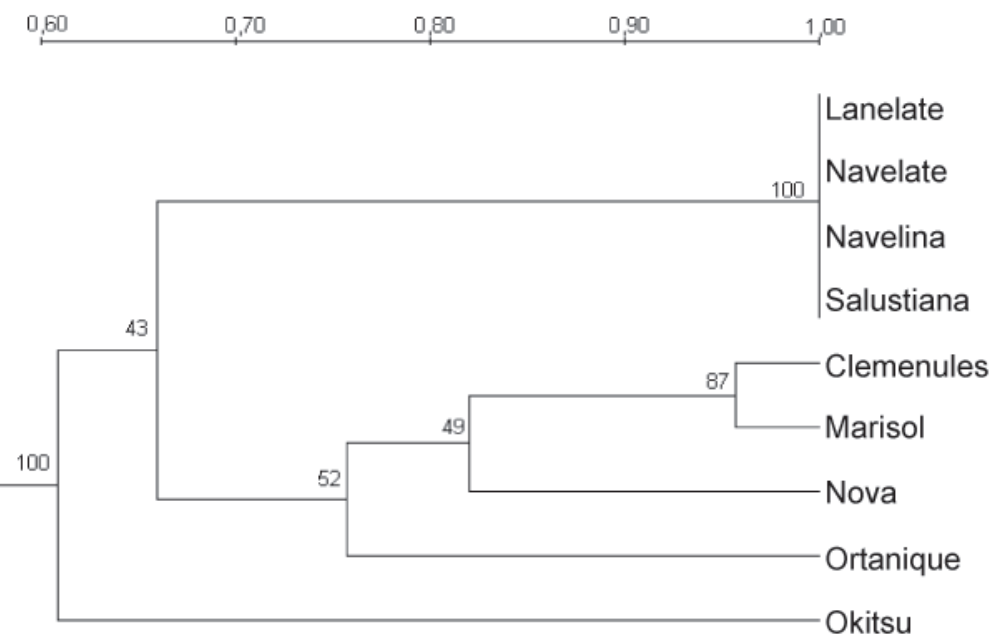

FIGURE 2 - Genetic diversity among citrus fresh fruit market cultivars obtained by the Jaccard coefficient and clustered by UPGMA (unweigthed pair group arithmetic average method). The consistency of each cluster was determined by bootstrap analysis.

similarity in relation to C. reticulata than those from C. reticulata $\mathrm{x} C$. sinensis.

Cultivar Okitsu satsuma had the highest genetic distance when compared to the other samples assessed (Table 1 and Figure 2), and this result was highly consistent through the bootstrap analysis $(100 \%)$. The genetic similarity of this cultivar varied from $G_{j} 0.7250$ ('Marisol') to $\mathrm{G}_{j} 0.8158$ ('Nova'). The polymorphism obtained in this work is not in accordance to the data reported by Swingle \& Reece (1967) and Coletta Filho et al. (1998), who considered all mandarins in a single species. This work also showed that the sweet orange cultivars (C. sinensis) had greater genetic similarity when compared to mandarins 'Clemenules' and 'Marisol' (C. reticulata) than in relation to satsuma 'Okitsu' (C. unshiu). This was an unexpected result even considering the hypothesis proposed by several authors that sweet orange cultivar C. sinensis could be natural hybrids and had C. reticulata as one of the parents (Scora, 1975; Barret \& Rhodes, 1976). Coletta Filho et al. (1998) also documented a lower genetic similarity between $C$. reticulata and C. unshiu when they assessed several mandarin cultivars; however, since they did not evaluate other plant materials, the differences were not relevant to distinguish the mandarin cultivars in more than one species. Certainly, the use of a higher number of polymorphic fragments and other species of Citrus will help to clarify this discussion.

\section{REFERENCES}

AGRIANUAL 2004: anuário da agricultura brasileira. São Paulo: FNP Consultoria \& AgroInformativos, 2004. 496p.

AYALA, F.J.; POWEL, J.R.; TRACEY, M.L.; MOURÃO, A.C.; PEREZ-
SALAS, S. Enzyme variability in the Drosophila willistoni group IV genic variation in natural populations of Drosophila willistoni. Genetics, Oxford, v.70, p.113-139, 1972.

BARRET, M.C.; RHODES, A.M. A numerical taxonomic study of affinity relationships in cultivated Citrus and its close relatives. Systematic Botany, Tallahassee, v.1, p.105-135, 1976.

CAMERON, J.W.; FROST, H.B. Genetics, breeding, and nucellar embryony. In: REUTHER, W.; BATCHELOR, L.D.; WEBBER, H.J. (Ed.). The citrus industry. Berkeley: University of California Press, 1968. v.2, p.325-370.

COELHO, A.S.G. BOOD: avaliação de dendrogramas baseados em estimativas de distâncias/similaridades genéticas através do procedimento de bootstrap. Goiânia: UFG, 2000. Software.

COLETTA FILHO, H.D.; MACHADO, M.A.; TARGON, M.L.P.N.; MOREIRA, M.C.P.; POMPEU JÚNIOR, J. Analysis of the genetic diversity among mandarins (Citrus spp.) using RAPD markers. Euphytica, Wageningen, v.102, p.133-139, 1998.

HERRERO, R.; ASÍNS, M.J.; CARBONELL, E.A.; NAVARRO, L. Genetic diversity in the orange subfamily Aurantioideae - I: Intraspecies and intragenus genetic variability. Theoretical and Applied Genetics, New York, v.92, p.599-606, 1996.

IBGE. Instituto Brasileiro de Geografia e Estatística. Disponível em: $<$ http:/ /www.ibge.gov.br>. Acesso em : 20 dez. 2004.

NOVELLI, V.M.; CRISTOFANI, M.; MACHADO, M.A. Evaluation of microsatellite markers in cultivars of sweet orange (Citrus sinensis (L.) Osbeck). Acta Horticulturae, The Hague, v.535, p.47-49, 2000.

OLIVEIRA, R.P.; CRISTOFANI, M.; AGUILAR-VILDOSO, C.I.; MACHADO, M.A. Diversidade genética entre híbridos de tangerina 'Cravo' e laranja 'Pêra'. Pesquisa Agropecuária Brasileira, Brasília, v.37, n.4, p.479-484, abril 2002.

ROHLF, F.S. NTSYS-pc: numerical taxonomy and multivariate analysis system. New York: State University of New York, 1992.

SCANDALIOS, J.G. Genetic control of multiple molecular forms of enzymes in plants: a review. Biochemical Genetics, New York, v.3, p.37-39, 1969.

SCORA, R.W. On the history and origin of citrus. Bulletin of the Torrey Botanical Club, Lancaster, v.102, p.369-375, 1975.

SHIELDS, C.R.; ORTON, T.J.; STUBBER, C.W. An outline of general resource needs and procedures for the electrophoretic separation of active enzymes from plant tissue. In: TANKSLEY, S.D.; ORTON, T.J. (Ed.). Isozymes in plant genetics and breeding. Amsterdan: Elsevier, 1983. p.443-468.

SWINGLE, W.T.; REECE, P.C. The botany of citrus and its wild relatives. In: REUTHER, W.; WEBBER, H.J.; BATCHELOR, L.D. (Ed.). The citrus industry. Berkeley: University of California, 1967. v.1, p.190430.

TANAKA, T. Fundamental discussion of Citrus classification. Study in Citrologia, Osaka, v.14, p.1-6, 1977.

VALLEJOS, C.E. Enzyme activity staining. In: TANKSLEY, S.D.; ORTON, T.J. (Ed.). Isozymes in plant genetics and breeding. Amsterdam: Elsevier, 1983. p.469-515. 